\title{
AN ENVIRONMENTAL COMPARISON OF PLASTIC AND PAPER CONSUMER CARRIER BAGS IN SOUTH AFRICA: IMPLICATIONS FOR THE LOCAL MANUFACTURING INDUSTRY
}

\author{
J. Sevitz ${ }^{1}$, A.C. Brent ${ }^{2}$ and A.B. Fourie ${ }^{1}$ \\ ${ }^{1}$ Department of Civil and Environmental Engineering \\ University of Witwatersrand, South Africa \\ sevitz@global.co.za \\ ${ }^{2}$ Chair: Life Cycle Engineering \\ Department of Engineering and Technology Management \\ University of Pretoria, South Africa \\ abrent@eng.up.ac.za
}

\begin{abstract}
The conventional consumer carrier bags have recently received considerable attention in South Africa. The choice of material for these bags, based on environmental preferences in the South African context, could significantly influence the local manufacturing industry. Life Cycle Assessment (LCA), an environmental management tool, has been applied to objectively evaluate and compare the overall environmental impacts of the complete life cycles (from raw material extraction to final disposal) of consumer plastic and paper carrier bags in South Africa. Paper bags have a higher carrying capacity compared to plastic bags and different use ratios were subsequently evaluated. Plastic bags have a lower environmental impact for use ratios of up to 2.5 plastic bags to one paper bag. Above this ratio the conclusions are not reliable. Paper bags would need to increase its recycled content significantly to be competitive in terms of environmental impacts. The re-use of thicker plastic, as proposed by the new plastic bag legislation, has the potential to significantly lower the impact of plastic bags.
\end{abstract}

\section{OPSOMMING}

Die konvensionele gebruikersdrasakke het onlangs aansienlike aandag in Suid Afrika ontvang. Die keuse van materiaal vir hierdie sakke, wat gebaseer is op omgewingsvoorkeure in die Suid-Afrikaanse konteks, kan 'n wesenlike invloed uitoefen op die plaaslike vervaardigingsindustrie. Lewenssiklusanalise (LCA), 'n omgewingsbestuurgereedskap, is aangewend vir 'n objektiewe evaluasie en vergelyking van die algehele omgewingsimpakte van die totale lewenssiklus (vanaf grondstofekstraksie tot finale wegdoening) van gebruikersplastiek- en papierdrasakke in Suid-Afrika. Aangesien papiersakke 'n hoër drakapasiteit het in vergelyking met plastieksakke, is verskillende gebruiksverhoudings evalueer. Plastieksakke het 'n laer omgewingsimpak vir gebruiksverhoudings tot en met 2.5 plastieksakke vir elke papiersak. Die gevolgtrekkings van die studie is nie betroubaar vir hoër verhoudings nie. Die persentasie hergesirkuleerde materiaal in papiersakke moet verhoog word om mededingend te wees in terme van omgewingsimpak. Die hergebruik van dikker plastiek, soos voorgestel deur die nuwe plastieksakwetgewing, het die potensiaal om die algehele impak van plastieksakke wesenlik te verlaag. 


\section{INTRODUCTION}

The conventional plastic carrier bag, found in almost all supermarkets, shops and stores, is often dubbed the new national flower of South Africa by the environmental media [1] due to its persistent presence in the natural environment. It has long been a contentious issue of what alternatives should be used to carry goods. This debate is usually based on the perceived importance of the relative environmental impacts of various alternatives, which include degradable plastic bags, thicker re-usable plastic bags, paper bags, cloth bags, cellulose bag, etc. This question is especially important now, in light of the new plastic bag regulations set by the South African national Department of Environmental Affairs and Tourism [2].

The required local support industries, and associated environmental impacts, are highly dependent on the type of alternative chosen for the typical High Density Polyethylene (HDPE) plastic bag. This study selected the common unbleached kraft paper bag to evaluate and compare the related impacts with the HDPE plastic bag in a South African context. Claims made as to which material choice is less environmentally damaging are often based on only one or two properties of these bags, e.g. the biodegradable nature of paper or the smaller volume and weight of plastic. In order to reach an objective and definitive answer as to which has less impact on the environment, the entire life cycle of these bags must be considered, i.e. from "cradle-to-grave". The life cycle consists of a chain of processes that includes raw material extraction, production, transportation, use, and disposal of the bags, and is illustrated in Figure 1. Each unit process utilises various inputs (natural resources and energy) and outputs (emissions and releases to air, water and land). Only by summing the burdens (and benefits) of all upstream and downstream processes for both competing products, can they truly be evaluated and compared.

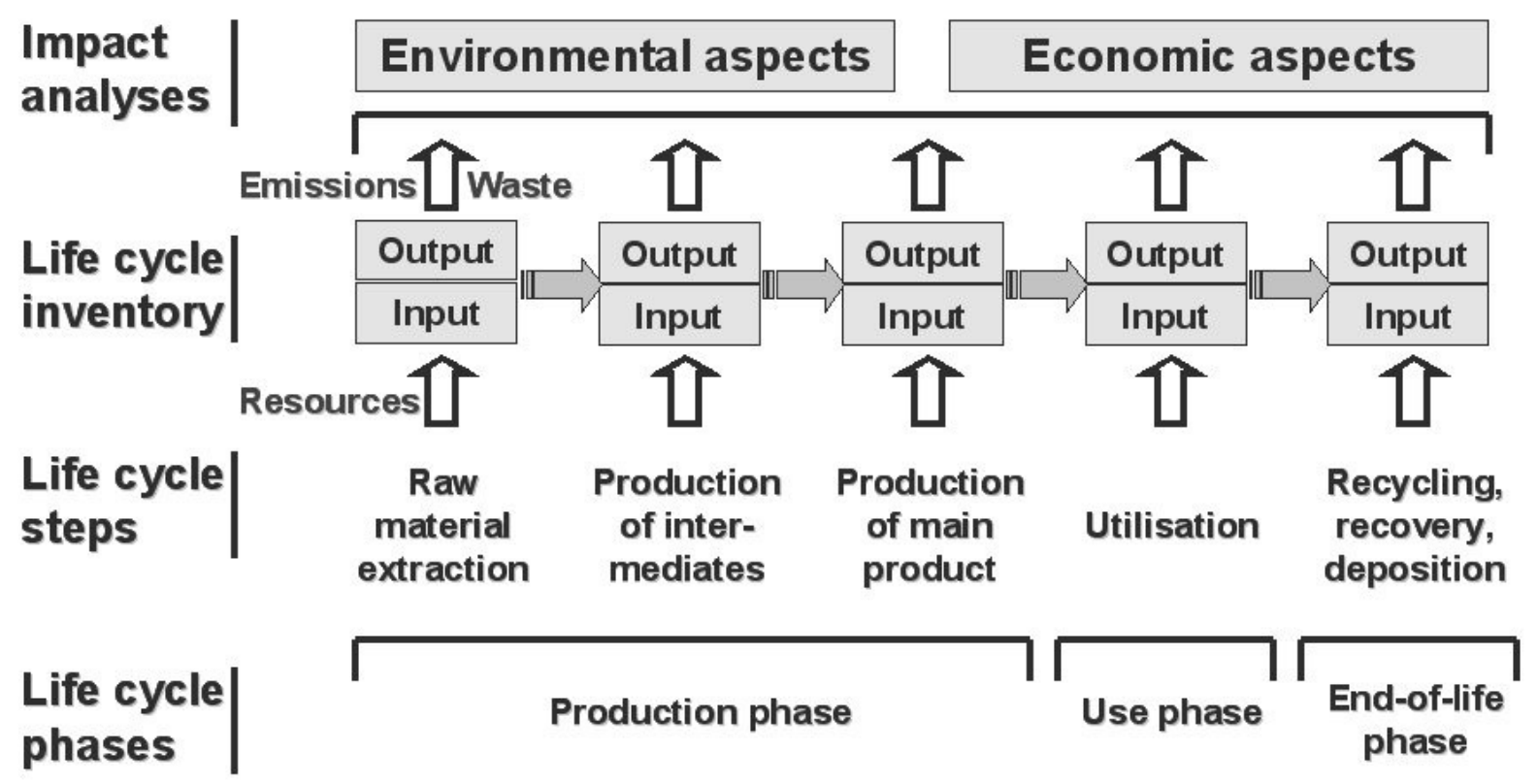

Figure 1: The life cycle approach for "cradle-to-grave" analyses

Life Cycle Assessment (LCA) is a standardised environmental management tool that quantitatively evaluates the environmental impacts of a product or activity across its entire life. According to the Society of Environmental Toxicology and Chemistry (SETAC) [3], the 
primary custodian of the technical developments in LCA, the tool can be invaluable in identifying environmental "hotspots" in a product's life cycle, as well as for quantitative comparisons of products.

\section{OVERVIEW OF THE LIFE CYCLE ASSESSMENT (LCA) METHODOLOGY}

LCA is a technical evaluation tool included in the 14000 family of environmental management standards of the International Organization for Standardization (ISO) [4]. The standardised LCA methodology is divided into four highly iterative phases, as described by ISO [5] and illustrated in Figure 2, i.e. goal and scope definition, inventory analysis, impact assessment, and interpretation.

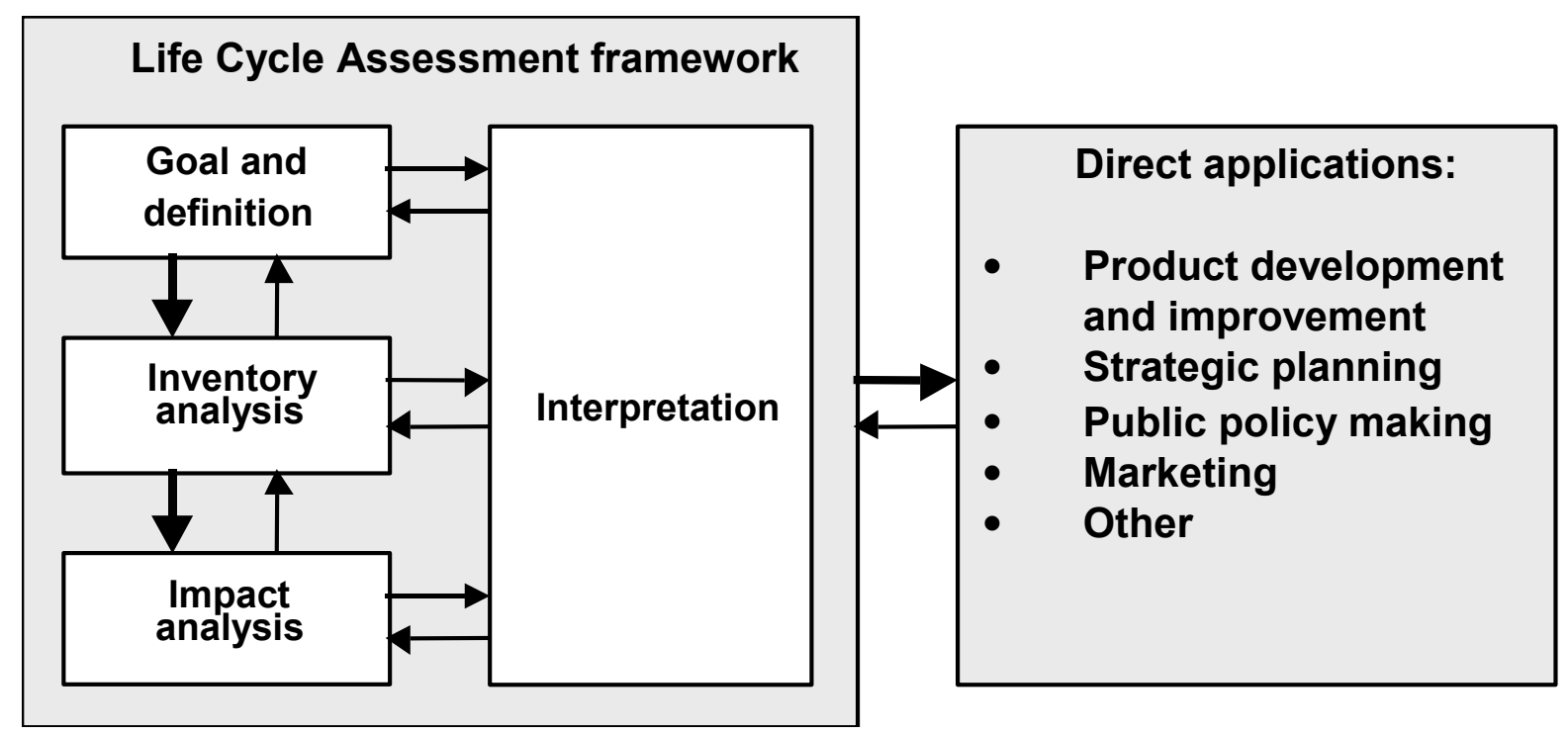

Figure 2: Standardised framework for the ISO LCA methodology

The goal and scope phase describes the purpose of the study and includes:

- Intended application and audience.

- Functions of the investigated life cycle system.

- Boundaries to the system.

- Key assumptions and limitations of the study.

- Allocation procedures for multiple product systems.

- Data and data quality requirements.

- $\quad$ Selected impact assessment methodologies.

The inventory analysis involves data collection and calculation procedures to quantify the inputs and outputs of the product system. Data collection is usually resource-intensive and practical constraints must therefore be considered (and reported).

The impact assessment (IA) phase evaluates the significance of potential environmental impacts using the results from the inventory analysis. These results are assigned to a set of environmental and health problems, called impact categories, such as global warming, human toxicity and resource depletion. The assignment process is referred to as classification. The 
potential impacts for the categories are then characterised by calculating each burden's contribution to the impact category. For example, the global warming category converts emissions into global warming potentials (GWP), expressed as equivalent kilograms of $\mathrm{CO}_{2}$. Methane, for instance, may be assigned a GWP value of 21 as its impact on global warming is 21 times that of Carbon Dioxide over a 100 year period after release to the atmosphere [6]. The first two IA steps, i.e. classification and characterisation, are mandatory for all LCA studies according to ISO [7]. Optional elements of the IA include normalisation and weighting. Normalisation divides the impact category results by a reference value, such as total world emissions for that category, in order to determine the relative significance of the impact categories in a specified area. These normalised impact categories can then be (subjectively) weighted relative to each other, so that a final single value can be determined to represent a product's overall impact.

The interpretation phase is where the results are analysed in relation to the goal and scope definition, where conclusions are reached, the limitations of the results are presented and where recommendations are provided based on the findings of the preceding phases.

\section{GOAL AND SCOPE DEFINITION OF THE COMPARATIVE STUDY}

The main objective of the study was to quantitatively compare the environmental implications of the life cycles of plastic and paper bags currently manufactured in South Africa. In addition, the effect of increasing the recycled content of these bags was briefly looked at. The effect of implementing the new plastic bag regulations is also addressed. The study aims to contribute to the understanding of decision makers in the manufacturing industry of the respective roles of industry sectors in the life cycles of different kinds of carrier bags.

\subsection{Functional unit of the comparative study}

Fundamental to any LCA is the functional unit, which defines the amount of product required to fulfil the function. It provides a reference to which data can be normalised. It is essential for a comparative LCA that the functional unit of each product fulfil the same function [5].

Through surveys of US supermarkets [8] it is evident that for paper and plastic bags of the same size, more plastic bags are used to hold the same amount of groceries. Ratios ranging from 1.2:1 to 3:1 plastic bags per paper bag have been reported, but there is no industry-wide agreement on a representative ratio. The volumetric capacity of the average paper bag as defined in this study is 1.57 times bigger than the average defined plastic bag. However, the paper bags from the United States studies were 1.43 times thicker (and thus able to hold more) than the paper bags for this study, which mostly negates the bigger size. This translates into ratios ranging from $1.5: 1$ to $3.7: 1$. Ratios ranging from $1: 1$ to $6: 1$ have been analysed, although ratios between $2: 1$ and $3: 1$ are probably more appropriate.

A functional unit for paper bags has been chosen as 1000 paper bags. The equivalent number of plastic bags consequently ranges from 1000 (for $1: 1$ ) to 6000 (for $6: 1$ ). 


\begin{tabular}{|c|c|c|c|c|c|c|}
\hline Bag & Material & $\begin{array}{c}\text { Recycled content } \\
(\%)\end{array}$ & $\begin{array}{c}\text { Weight } \\
\text { (g) }\end{array}$ & $\begin{array}{r}\text { Thickness } \\
\left(\mu \text { or } \mathbf{g} / \mathbf{m}^{2}\right)\end{array}$ & $\begin{array}{c}\text { Capacity } \\
\text { (litres) }\end{array}$ & $\begin{array}{c}\text { Cost } \\
\text { (cents) }\end{array}$ \\
\hline Plastic & HDPE & $18^{\mathrm{a}}$ & 5.96 & $16.35 \mu$ & 14 & 6.93 \\
\hline Paper & Bleached kraft & 0 & 52.85 & $80 \mathrm{~g} / \mathrm{m}^{2}$ & $24.2^{\mathrm{b}}$ & 31.70 \\
\hline \multicolumn{7}{|c|}{$\begin{array}{l}\text { a Average value. The recycled content of plastic bags can vary from } 0 \% \text { to } 95 \% \text {. } \\
\text { b Dimensions based on a study done by Nedlac [9], an organisation that researched the socio-economic } \\
\text { impacts of the plastic bag regulations proposed by government. }\end{array}$} \\
\hline
\end{tabular}

Table 1: Specifications of the plastic and paper carrier bags as basis for this study

\subsubsection{Description of the investigated carrier bags}

Although there are a number of standard sized bags, there are variances in dimension, thickness, weight and recycled content. Weighted averages have been calculated from the data collected from industry [10], resulting in an average plastic and paper carrier bag, which has been used as the basis of this study. The specifications of these bags are summarised in Table 1.

\subsection{Boundaries of the comparative study}

The boundaries of the life cycles of the carrier bags include the cradle-to-gate manufacturing of the respective amount of bags, as well as the transport required in the use stage and the final disposal. Auxiliary processes required for the life cycles include electricity generation and liquid fuel production for transportation processes.

\subsubsection{The life cycle of plastic bags}

The manufacturing of plastic bags involves extruding and blowing pelletised HDPE (with $4.7 \%$ coloured pellets). The HDPE is polymerized from ethylene by DOW Plastics in Sasolburg, South Africa [10]. The ethylene feed consists of $15 \%$ propane gas from Natref (Sasolburg), 67\% ethane gas from Sasol Polymers (Sasolburg) and 18\% from other C2 hydrocarbons. The propane is a product of the refining of crude oil, which comes from the Middle East, West Africa and the North Sea. The ethane comes from the coal gasification processes of Sasol in Secunda. The coal is from Sasol's mining operations in South Africa.

The recycled content is almost all from in-house scrap recycling or from bags being sent back from retailers for various reasons. Post-consumer recycling accounts for less than $1 \%$ because of their low market value in South Africa [10]. It was consequently assumed that all the bags are disposed of on general municipal landfill sites.

\subsubsection{The life cycle of paper bags}

The very few manufacturers who make paper grocery bags use unbleached sack kraft paper from the Sappi Tugela Mill in Mandini, situated in the KwaZulu-Natal Province of South Africa [10]. Mostly pine and some gum logs are crushed and pulped and made into different papers. The unbleached kraft made for sacks contains no recycled content as it weakens the paper. Most of the logs come from the forests operated by Sappi Forestry in Pietermaritzburg, South Africa. 
No data was obtained for the recycling of paper bags into other paper products. It has therefore been assumed that all discarded paper bags are land filled.

\subsection{Data Collection}

Data for the plastic bag LCA was collected from 10 plastic bag manufacturers and 2 plastic bag recyclers (covering 75\% of the approximate 30000 tons of HDPE carrier bags made in South Africa), as well as 2 coloured pellet producers and 1 ethylene producer. Data for the paper bags was obtained from 2 paper bag manufacturers (no other known manufacturers could be identified who make paper bags specifically for grocery shopping), 1 kraft paper mill and 1 forestry company. For these companies, data was obtained by questioning one or several managers and technicians about the inputs and outputs associated with the relevant processes.

\subsubsection{Limitations and Data Quality}

Data was found to be sparse and lacking as a general rule (often the case for any LCA, but particularly so for South African industries). Several problems were encountered in obtaining the data from these companies and others who did not provide any data. This included the following:

- Data was considered to be confidential.

- Data was not available or accessible. The specificity of data required was different to what the companies normally require for their business purposes.

- Data was technically difficult to obtain (for example, the allocation of inputs and outputs to the hundreds of products that arise from the coal gasification plant).

- $\quad$ System boundaries could not always be simply defined.

- There was not sufficient time to fully investigate and analyse the individual unit processes to obtain the required amount of data (which can each take up to 6 months).

These problems were (in part) solved through the following procedures:

- Aggregated data was used with basic allocation methods. For example, the total emissions were divided by total product output (which would then include products not relevant to the study) in order to get the emissions per tonne of product.

- $\quad$ European and United States databases were used where there was a considerable lack of data for certain processes [11].

- $\quad$ South African data was integrated with European and US data for processes that had incomplete data.

The result of this was that the overall quality of data would not be as high as desired, as the data was more aggregated, and not necessarily an accurate reflection of the South African processes. Furthermore, the environmental impact assessment methodologies that are typically used in LCA studies have been developed for European countries, and therefore do not necessarily reflect accurate conditions in South Africa. Despite all of these limitations, the LCA nevertheless produces a reasonable first order approximation of the environmental profiles of the different carrier bag life cycles. 


\subsection{Selected impact assessment methodologies}

Several impact assessment methodologies are commercially available to be used by LCA practitioners. These procedures have been developed in Europe to remove the complexity of the impact analysis phase for practitioners. Three methods were compared to check for consistency between the relative impacts of the two bag types:

- $\quad$ The Eco-indicator 99 method from Pré Consultants in the Netherlands [12].

- $\quad$ The Ecopoints method developed by BUWAL, Switzerland [13].

- The CML methodology from Leiden University in the Netherlands [14].

These three methods include a normalisation step, which is based on Western European emissions and resource-use data. The CML method does not included the final weighting step, which is a highly subjective matter, e.g. deciding whether human health issues are more or less important than damages to the ecosystem, or depletion of non-renewable resources. This step is consequently not recommended by ISO [7] when the results are intended for public comparison. Rather, the individual impact categories should be compared against each other. Weighting is usually applied internal to a company for design purposes when choosing between alternatives. The designer can then select which weighting set is more appropriate for the product and company's purposes. In this study, four different IA weighting sets are used to determine if any consistency exists across the methods that would indicate the usefulness of singles scores (for this study alone). Individual impact categories as well as single scores are therefore considered. The weighting sets are determined as follows:

- The Eco-indicator 99 method used a panel procedure, whereby the opinion of a selected panel of expertise is used to determine weighting factors for the impact categories. The results of the survey have been grouped into three distinct perspectives or separate weighting sets, i.e. hierarchist, egalitarian and individualist [12]. The hierarchist is the default weighting set, which uses a balanced time perspective where consensus among scientists determines inclusion of effects. Egalitarian is a long time perspective where even a minimum of proof justifies inclusion, and the individualist set refers to a short time perspective where only proven effects are included.

- The Ecopoints method used a distance-to-target procedure, whereby weighting factors are determined by the ratio of current impact levels in Switzerland, compared to target levels set by Swiss policy [13].

\section{INVENTORY DATA FOR THE COMPARATIVE STUDY}

Figures 3 and 4 show the process flow diagrams for the plastic and paper life cycle systems for which the individual environmental impacts are determined. Detailed inventories are contained within a SimaPro LCA software database, situated at the CSIR, South Africa. 


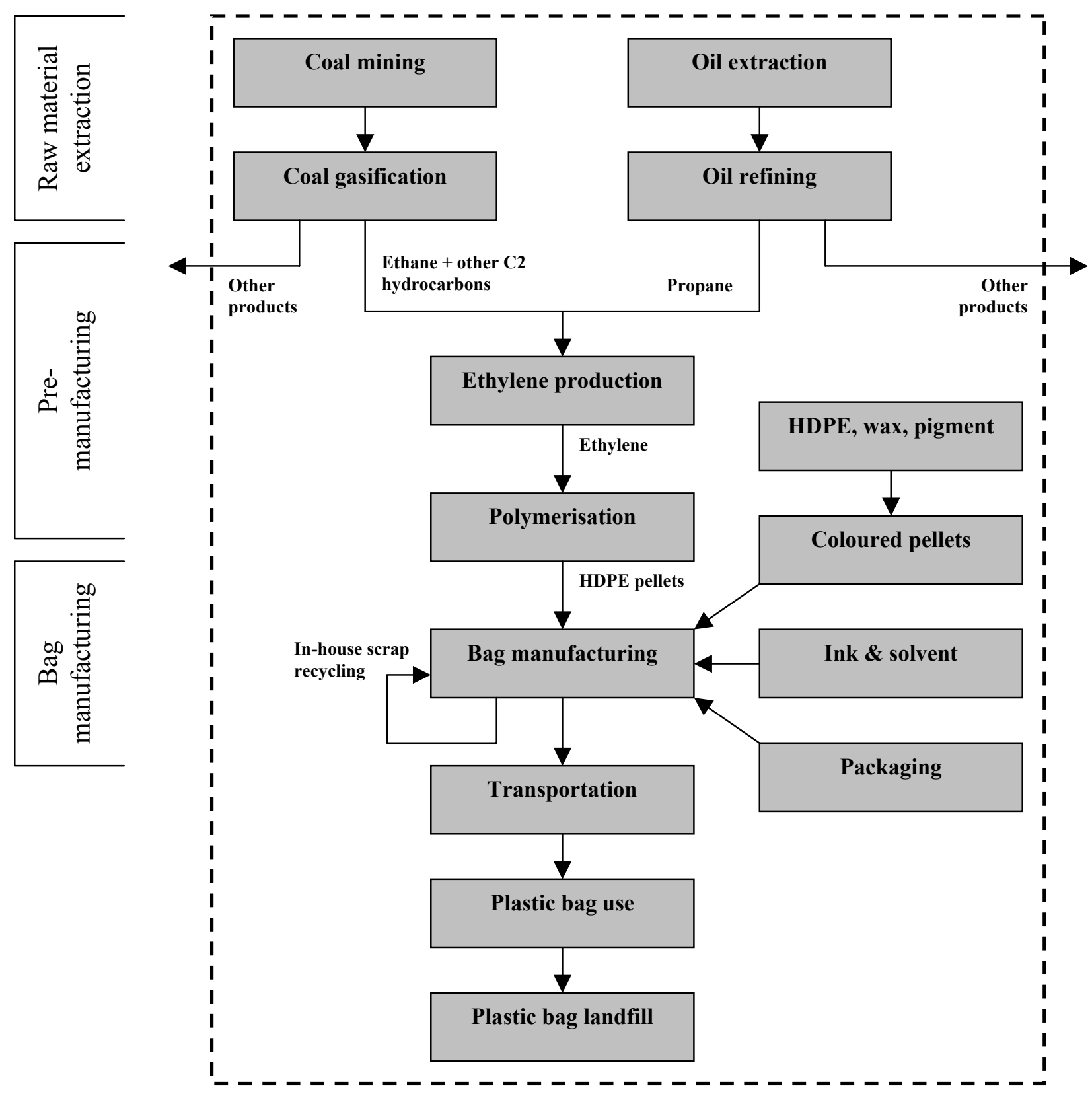

Figure 3: Flow diagram of the investigated plastic bag life cycle system

\section{IMPACT ANALYSES OF THE LIFE CYCLE SYSTEMS}

\subsection{Classification and characterisation}

Figure 5 shows the relative impact for different use ratios of plastic bags to paper bags across the impact categories for the classification and characterisation steps of the Eco-indicator 99 impact analysis method.

The plastic bag has lower impacts across all categories for ratios of less than 2.6 plastic bags to one paper bag. At this ratio the Fossil Fuel Depletion impact (initial threshold) is the same 


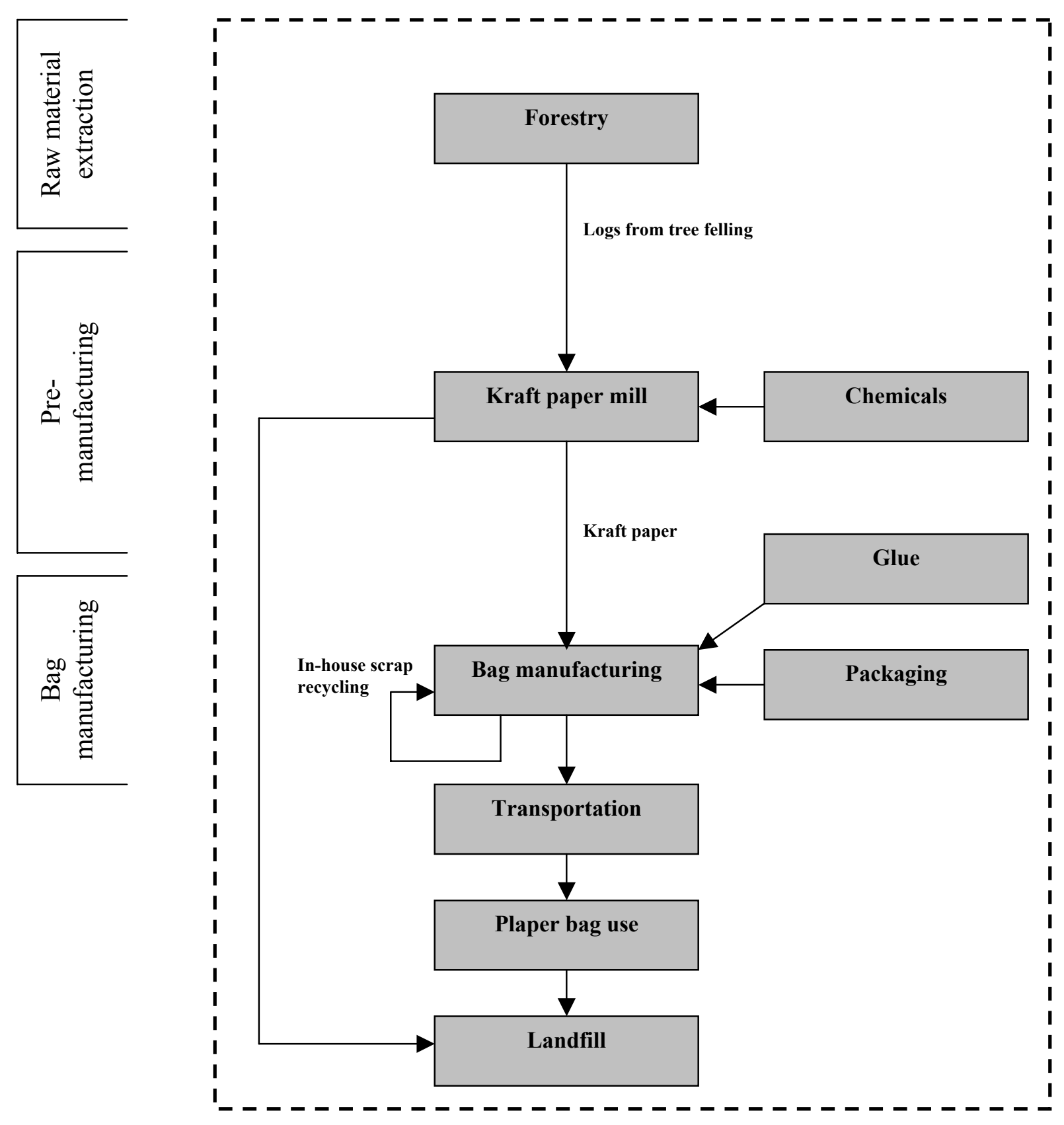

Figure 4: Flow diagram of the investigated paper bag life cycle system

for both bags. The next category to reach an equal impact for both bags is Acidification and Eutrophication (secondary threshold), which requires a ratio of 3.8. The initial threshold ratio for the Ecopoints method is 3.3 for the Sulphur Oxides $\left(\mathrm{SO}_{\mathrm{x}}\right)$ category. The secondary threshold ratio is 4.0 for the Nitrous Oxides $\left(\mathrm{NO}_{\mathrm{x}}\right)$ category. For the CML method, the initial threshold category is Human Toxicity, which has a value of 2.8, and the secondary category is Acidification at 3.5. The main inventory constituents that contribute to the environmental impacts of the life cycle systems are coal usage (Fossil Fuel Depletion), $\mathrm{SO}_{2}$ and $\mathrm{NO}_{\mathrm{x}}$ air emissions (Acidification Potential) and $\mathrm{SO}_{\mathrm{x}}, \mathrm{NO}_{\mathrm{x}}$ and metals air emissions (Human Toxicity), all mainly attributable to electricity generation and fuel production from coal in South Africa. 


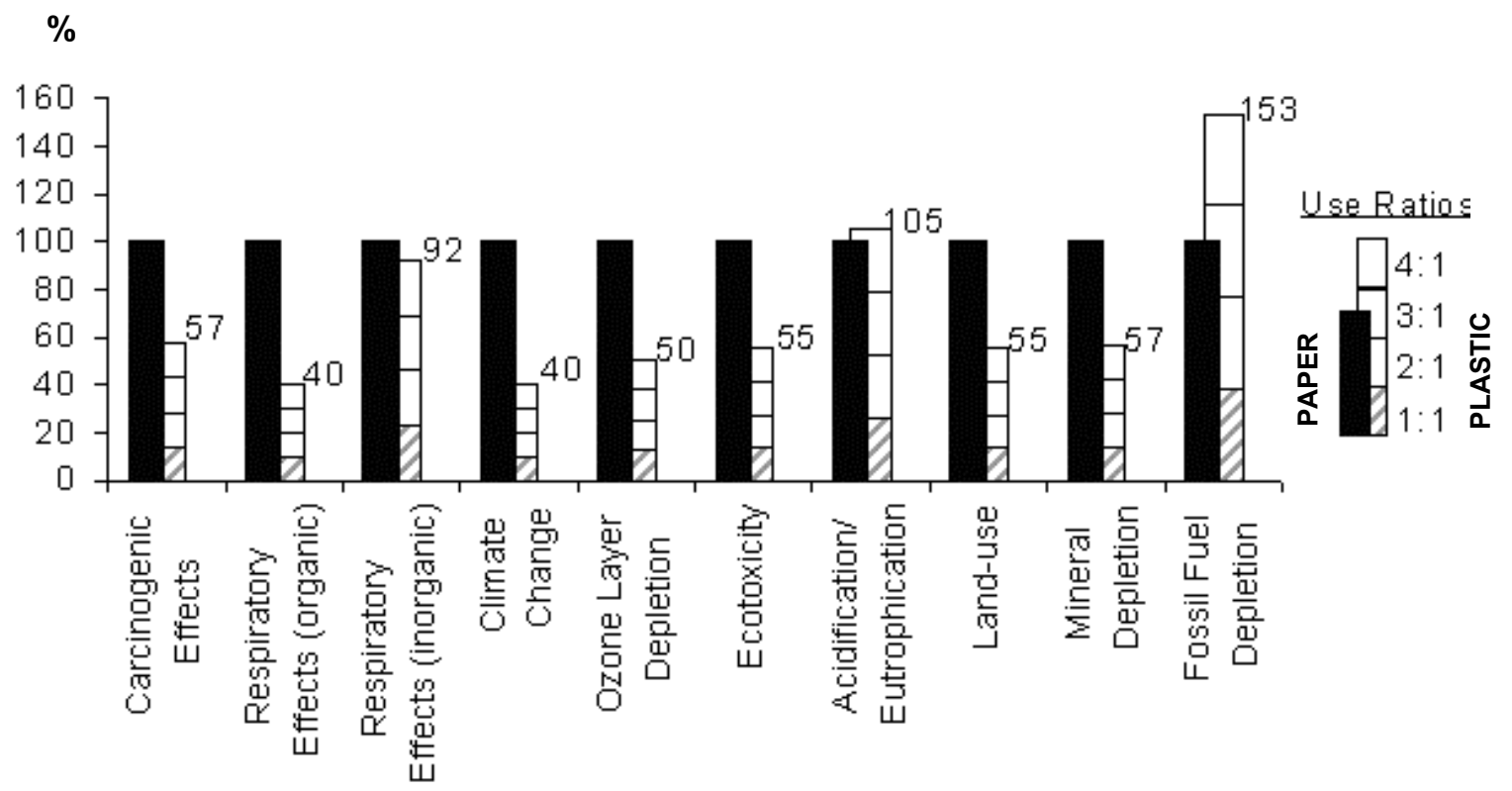

IMPACT CATEGORIES

Figure 5: Relative impact for different use ratios of plastic bags to paper bags for the impact categories of the Eco-indicator 99 methodology (values are normalised to $100 \%$ of the impact for the paper bags)

\subsection{Normalisation and weighting}

The results of the classification and characterisation steps of the impact assessment become increasingly complex to interpret and draw conclusions when different categories begin to favour the different bag types. For these cases, subjective weighting of the categories can assist the interpretation phase of the LCA. Therefore, beyond the initial threshold ratio of 2.6, single indicators are used for the analysis. For the Eco-indicator 99 method and applying the hierarchist single score weighting set, the use of 4.7 plastic bags are shown to have less environmental impacts compared with a paper bag. Although there is a much greater degree of subjectivity in weighted impacts (so that this ratio could be higher or lower than 4.7), the ratio will have a definite minimum of 2.6 (from the initial category ratio). The other weighting sets, i.e. egalitarian and individualist, increases this ratio to 6.0 and 6.2 respectively. For the Ecopoints method, the distance-to-target single score procedure indicates 5.7 plastic bags per paper bag. The impact analysis results with the three chosen methodologies are summarised in Figure 6.

\section{INTERPRETATION OF THE COMPARATIVE STUDY}

The interpretation phase of a comparative LCA study is inherently complicated when the uncertainties of the chosen environmental indicators are generalised. The nature of error in these analyses is systematic and not due to randomness. Thus, the margin of error cannot be statistically determined. In the Eco-indicator 99 method's Manual for Designers [15], provisional and general guidelines are suggested for dealing with data uncertainties. If the 


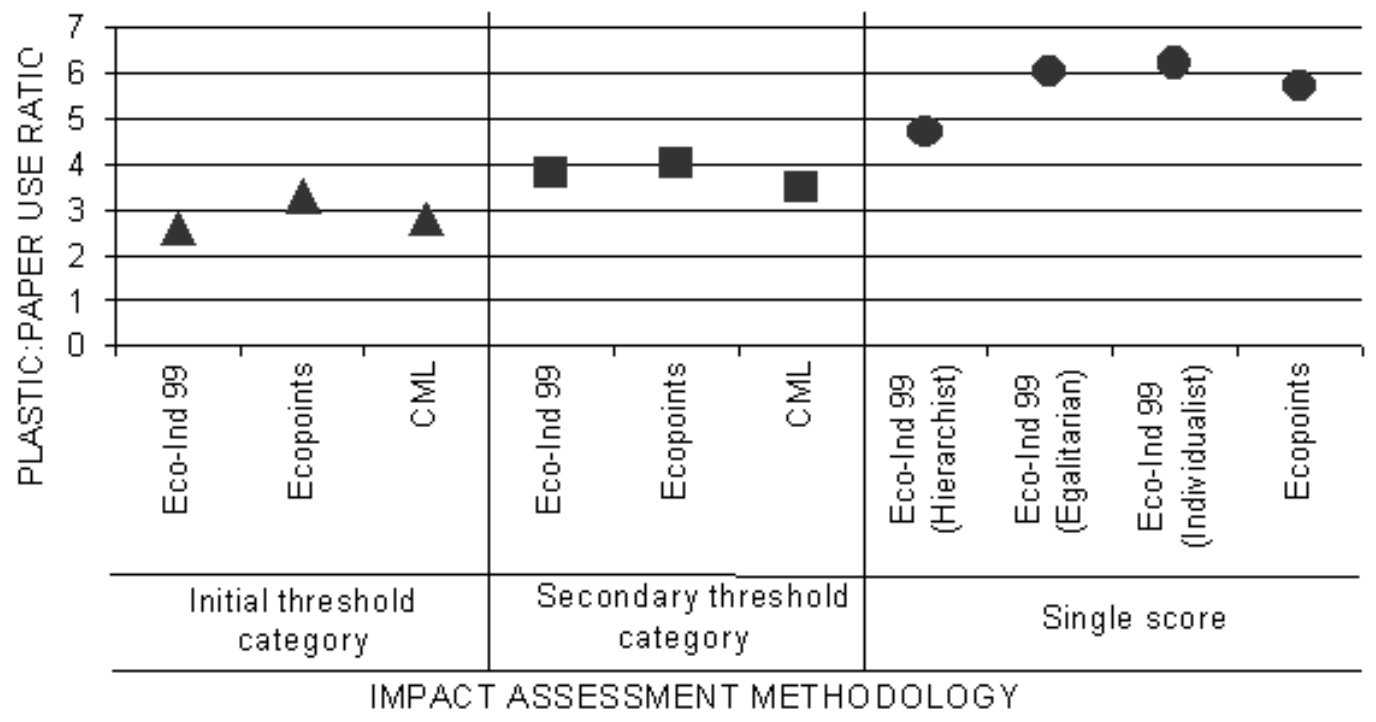

Figure 6: Summary of the use ratios for different impact assessment methodologies

dominant processes (with the highest contributions) are considered to be similar (for example if products are made from different plastics both based on oil refining), the difference between the eco-indicator scores should be 10 to $50 \%$ if a reliable conclusion is to be drawn on which one is the best option. Uncertainties from flaws in data or analysis models for similar processes will then be correlated and therefore will tend to compensate each other. For dissimilar or completely different processes, the scores should differ at least by $100 \%$ before reliable conclusions can be drawn. The dominant processes of this study are shown in Table 2.

\begin{tabular}{|l|c|l|c|}
\hline \multicolumn{1}{|c|}{ Paper bag life cycle } & $\begin{array}{c}\text { Percentage } \\
\mathbf{( \% )}\end{array}$ & \multicolumn{1}{|c|}{ Plastic bag life cycle } & $\begin{array}{c}\text { Percentage } \\
\mathbf{( \% )}\end{array}$ \\
\hline Total electricity generation (coal) & 58.8 & Total electricity generation (coal) & 39.4 \\
\hline \multirow{2}{*}{ Kraft production (paper mill) } & 33.3 & Coal gasification & 34.9 \\
\cline { 2 - 4 } & Oil refinergy & 11.3 \\
\hline TOTAL & $\mathbf{9 2 . 1}$ & TOTAL & $\mathbf{8 5 . 6}$ \\
\hline
\end{tabular}

Table 2: Dominant processes $(>10 \%)$ of the of the paper and plastic bag life cycles

The production processes are not similar, but both life cycles are quite energy intensive. Because the South African data that has been collected is exceedingly aggregated for the unit processes, i.e. local data has been combined with European and United States data, and has been assessed with European impact assessment methodologies, the uncertainty of accuracy is relatively high. The indicator scores should therefore differ by at least $100 \%$ for a reliable conclusion.

The ratios of the IA methods have been divided by the actual proposed ratios of plastic to paper bags to obtain a new value. Where this value is greater than 2 (a $100 \%$ difference 
represents a factor of 2 , i.e. double) it can be concluded that plastic bags have a lower impact than paper bags. Where this value is less than 0.5 it can be concluded that paper bags have a lower impact than plastic bags. In between these two values reliable conclusions cannot be reached. This is shown in Figure 7. The lines connecting the points are for ease of readability in that they connect points of equal ratios, but they do not directly relate to each other.

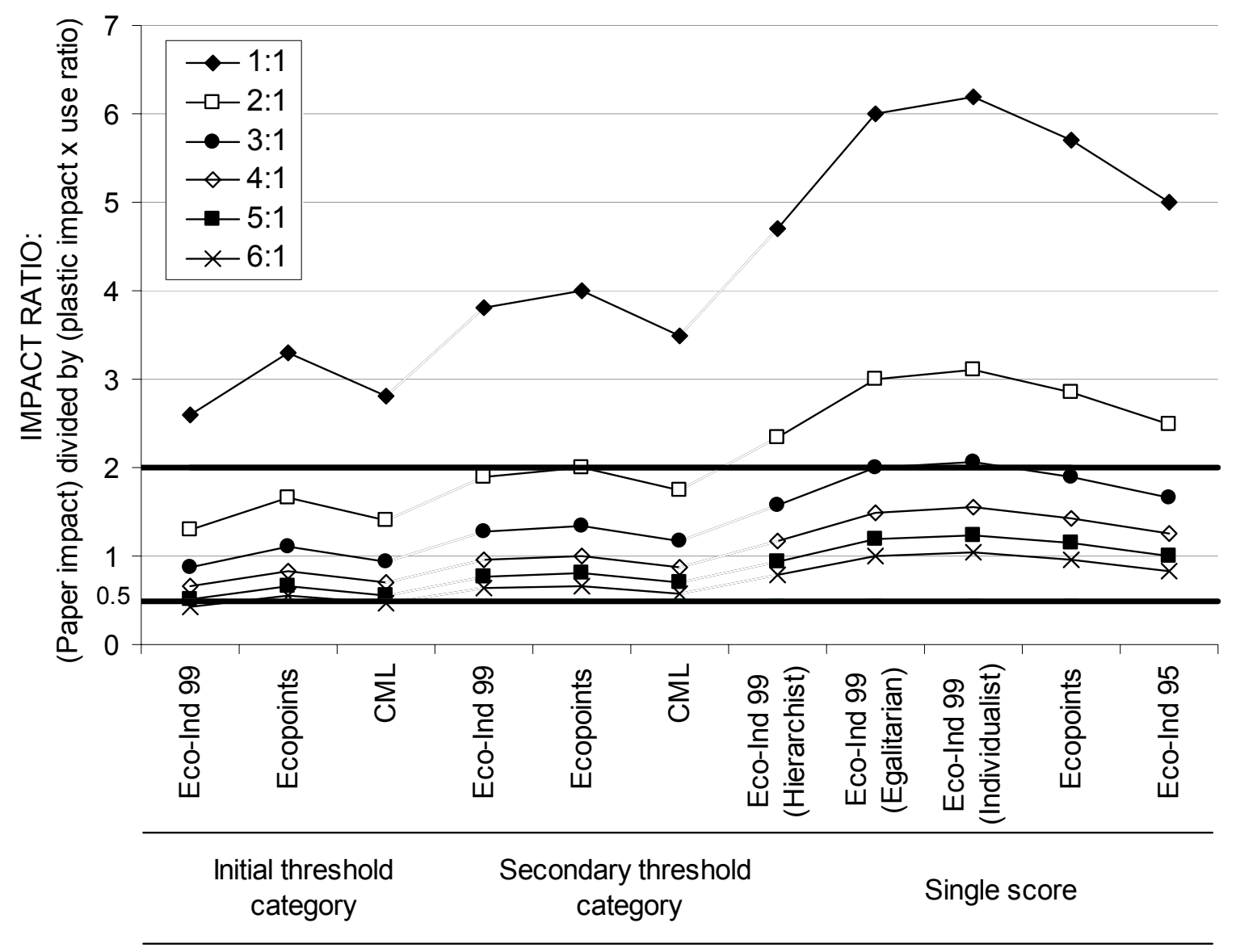

\section{IMPACT ASSESSMENT METHODOLOGY} Figure 7: Impact Assessment results ratios divided by use ratios to draw reliable
conclusions regarding the environmental superiority of plastic or paper bags

The graph indicates that for a ratio of $1: 1$, plastic is better than paper for all impact assessment methods. For a ratio of 2:1 all single score methods indicate that plastic is better than paper. It must be noted that although there is subjectivity in single scores, all methods indicate results of similar magnitude. This consistency suggests that there is validity in using these single scores. For the volumetric ratio of 1.57 plastic bags per paper bag (see the defined functional unit of section 3.1), the results likely favour plastic as the material of choice. Towards the 3:1 ratio, the points start dropping below the upper limit. Almost all other methods with ratios up to $6: 1$ fall between the two limits, where reliable conclusions cannot be drawn. Only from a ratio of 6:1 and up do single impact categories begin to favour paper. Only at a ratio of 21:1 is paper indisputably better than plastic across all categories. 


\section{CARRIER BAG RECYCLING}

Although various factors (such as economics, strength properties and hygiene) hinder the use of recycled material for the bags, recycling scenarios were nevertheless considered to determine if there would be any dramatic changes in environmental impacts of the life cycle systems.

The use of non-virgin HDPE is very similar to that of virgin bag production. More water will be used for washing the non-virgin material, but data for this was lacking, and therefore not included. The paper kraft production process (paper mill) is where the recycled material can be re-pulped and made into kraft paper for the bags. European data for a gate-to-gate process for the production of kraft paper from mostly recycled material was used, which would substitute impacts from the re-pulping process.

Using the default Eco-indicator 99 methodology (the more conservative single score method for this study, as shown in Figure 6), the impact of plastic recycling reduces more rapidly than that of paper for use ratios above 2:1, and vice versa for ratios of 2 and below. In order for the paper bag to begin being environmentally competitive, it would have to increase it's recycled content (while current plastic recycling trends remains at $18 \%$ ), above $13 \%$ for a use ratio of $5: 1$, above $62 \%$ for a use ratio of $4: 1$, and about $100 \%$ for a ratio of $3: 1$. Note that there must still be a difference of $100 \%$ for a reliable result.

Where the recycling of appropriate material for bags is considered, care must be taken of the infrastructure that is required for a viable and self-sustaining manufacturing industry. The collection scenarios of disposed material, especially, have been shown to be of primary importance to reduce costs and environmental implications where the recycling of other types of materials in South Africa has been evaluated [16].

\section{THE NEW PLASTIC REGULATIONS}

As of the 9th of April 2003, any plastic carrier bag manufactured or distributed that is less than 30 microns thick will be illegal [2]. There has been much controversy over this new law, which has been heavily rejected by the industrial and retail sectors. The intention was to decrease the unsightly litter problem and increase recycling, by people re-using the bags or collecting them for recycling (as they would then have a higher market value). The printing of bags under 80 microns thick has also been banned to make them more viable for recycling. A report from Nedlac [9] focuses more on the socio-economic implications. This study has briefly considered the environmental implications of the re-use of the plastic bags.

Two scenarios were analysed for the impact of these regulations. In the first case, it is assumed that the new 30-micron plastic bags are produced in South Africa, with processes similar to the current manufacturing sector. Although new equipment would have to be purchased for this (the expense of this equipment is one of the reasons why manufacturers will not be producing the new bags), the new capital equipment was not included in the analysis (neither was the equipment for the 16.35-micron bags). The second scenario looks at the impact of the bags being produced in Europe (one possibility) and transported by sea to South Africa. Thus, only European production processes were selected for this. 
The Eco-indicator 99 method (hierarchist perspective) has been used for these two scenarios. The impact for the 30-micron bags increases from 1.4 Eco-indicator points (for the 16.35 micron bags) to 2.5 points for production in South Africa, and 4.4 points for European production and transportation by sea. This means that South African consumers would need to use their bags more than 1.8 times (South African production) or 3.1 times (European production) for the impact to be lower that that of the current situation. If no South African companies produce the new bags, the closed-loop recycling with the bag industry will not be possible and the bags will most likely be recycled into HDPE pipes.

\section{CONCLUSIONS}

As a first order assessment, it can be reliably concluded that plastic bags have a smaller environmental footprint for use ratios of up to 2.5 plastic bags to one paper bag. Above this ratio, the uncertainty of data accuracy is too high to form reliable conclusions. Only for very high ratios of 7:1 and above does the paper bag begin to compete with the plastic bag. Paper bags would have to substantially increase their recycled content in order to be environmentally competitive.

If the new 30 micron bags are re-used, as intended, the potential decrease in impact could be considerable, although the social and economic impact must be weighed up against the environmental impact. The conversion of the existing manufacturing processes, specifically, could significantly influence the local industry and should be considered together with the environmental benefits.

\section{REFERENCES}

[1] Environmental News Network (2002): South Africa moves to weed out ugly national flower. Reuters, http://www.enn.com/

[2] Department of Environmental Affairs and Tourism (2002): Plastic bag regulations. http://www.environment.gov.za/

[3] Fava, J.A.; Densison, R.; Jones, B.; Curran, M.A.; Vigon, B.; Selke, S.; Barnum, J. (editors) (1991): A technical framework for life cycle assessment. Society of Environmental Toxicology and Chemistry (SETAC), Smuggler's Notch VT. Pensacola FL: SETAC Pr

[4] International Organization for Standardization (1998): ISO 14000 - Meet the whole family. ISO Central Secretariat

[5] International Organization for Standardization (1997): Environmental Management Life Cycle Assessment - Principles and Framework. ISO 14040: 1997

[6] Guinée, J.B.; Gorrée, M.; Heijungs, R.; Huppes, G.; Kleijn, R.; de Koning, A.; van Oers, L.; Sleeswijk, A.W.; Suh, S.; de Haes, H.A.U.; de Bruijn, H.; van Duin, R.; Huijbregts, M.A.J. (2001): Life Cycle Assessment - an operational guide to the ISO standards. Final report, Centre for Environmental Studies, Leiden University, the Netherlands

[7] International Organization for Standardization (2000): Environmental Management Life Cycle Assessment - Life Cycle Impact Assessment. ISO 14042: 2000

[8] American Plastics Council (2000): Plastics resource - information on plastics and the environment. http://www.plasticsresource.com 
[9] Nedlac (2001). Report: Socio-Economic Impact of the Proposed Plastic Bag Regulations. http://www.nedlac.org.za/research/fridge/plastics/index.html

[10] Sevitz, J. (2002): Personal communications

[11] Pré Consultants (2001): SimaPro 5.07 LCA software. http://www.pre.nl

[12] Goedkoop, M.; Spriensma, R. (2000): The eco-indicator 99 - a damage oriented method for life cycle impact assessment. Methodology report, Pré Consultants B.V.

[13] Braunschweig, A.; Bär, P.; Rentsch, C.; Schmid, L.; Wüest, G. (1998): Bewertung in ökobilanzen mit der methode de ökologischen knappheit: ökofaktoren 1997.Bundesamt für Umwelt, Wald und Landschaft (BUWAL)

[14] Guinée, J.B.; Gorrée, M.; Heijungs, R.; Huppes, G.; Kleijn, R.; de Koning, A.; van Oers, L.; Sleeswijk, A.W.; Suh, S.; de Haes, H.A.U.; de Bruijn, H.; van Duin, R.; Huijbregts, M.A.J. (2001): Life cycle assessment - an operational guide to the ISO standards. Centre for Environmental Studies (CML), Leiden University

[15] Goedkoop, M.; Spriensma, R. (1999): Eco-indicator 99. A damage orientated method for Life Cycle Impact Assessment. Manual for Designers, second edition, Pré Consultants B.V.

[16] Brent, A.C.; Rohwer, M.B. (2000): Life cycle assessment and costing: Infrastructure for the recycling of PET in South Africa. CSIR report for DACST Innovation Fund, 8600/86DD/HT243 Environmental News Network (2002): South Africa moves to weed out ugly national flower. Reuters, http:/www.enn.com/

[17] Department of Environmental Affairs and Tourism (2002): Plastic bag regulations. http://www.environment.gov.za/

[18] Fava, J.A.; Densison, R.; Jones, B.; Curran, M.A.; Vigon, B.; Selke, S.; Barnum, J. (editors) (1991): A technical framework for life cycle assessment. Society of Environmental Toxicology and Chemistry (SETAC), Smuggler's Notch VT. Pensacola FL: SETAC Pr

[19] International Organization for Standardization (1998): ISO 14000 - Meet the whole family. ISO Central Secretariat

[20] International Organization for Standardization (1997): Environmental Management Life Cycle Assessment - Principles and Framework. ISO 14040: 1997

[21] Guinée, J.B.; Gorrée, M.; Heijungs, R.; Huppes, G.; Kleijn, R.; de Koning, A.; van Oers, L.; Sleeswijk, A.W.; Suh, S.; de Haes, H.A.U.; de Bruijn, H.; van Duin, R.; Huijbregts, M.A.J. (2001): Life Cycle Assessment - an operational guide to the ISO standards. Final report, Centre for Environmental Studies, Leiden University, the Netherlands

[22] International Organization for Standardization (2000): Environmental Management Life Cycle Assessment - Life Cycle Impact Assessment. ISO 14042: 2000

[23] American Plastics Council (2000): Plastics resource - information on plastics and the environment. http://www.plasticsresource.com

[24] Nedlac (2001). Report: Socio-Economic Impact of the Proposed Plastic Bag Regulations. http://www.nedlac.org.za/research/fridge/plastics/index.html

[25] Sevitz, J. (2002): Personal communications

[26] Pré Consultants (2001): SimaPro 5.07 LCA software. http://www.pre.nl

[27] Goedkoop, M.; Spriensma, R. (2000): The eco-indicator 99 - a damage oriented method for life cycle impact assessment. Methodology report, Pré Consultants B.V.

[28] Braunschweig, A.; Bär, P.; Rentsch, C.; Schmid, L.; Wüest, G. (1998): Bewertung in ökobilanzen mit der methode de ökologischen knappheit: ökofaktoren 1997.Bundesamt für Umwelt, Wald und Landschaft (BUWAL) 
[29] Guinée, J.B.; Gorrée, M.; Heijungs, R.; Huppes, G.; Kleijn, R.; de Koning, A.; van Oers, L.; Sleeswijk, A.W.; Suh, S.; de Haes, H.A.U.; de Bruijn, H.; van Duin, R.; Huijbregts, M.A.J. (2001): Life cycle assessment - an operational guide to the ISO standards. Centre for Environmental Studies (CML), Leiden University

[30] Goedkoop, M.; Spriensma, R. (1999): Eco-indicator 99. A damage orientated method for Life Cycle Impact Assessment. Manual for Designers, second edition, Pré Consultants B.V.

[31] Brent, A.C.; Rohwer, M.B. (2000): Life cycle assessment and costing: Infrastructure for the recycling of PET in South Africa. CSIR report for DACST Innovation Fund, $8600 / 86 \mathrm{DD} / \mathrm{HT} 243$ 